\section{AMERICAN AWARDS TO BRITISH MEN OF SCIENCE}

$\mathrm{T}$ HE Medal for Merit, which has its origin in an order by President Washington, is the highest award made by the Government of the United States to a civilian. We print below the names of British men of science recently awarded the Medal, with the accompanying citations :

Sir Edward Appleton, for exceptionally meritorious conduct in the performance of outstanding services to the United Nations. Sir Edward, as secretary of the Department of Scientific and Industrial Research and chairman of the British National Committee for Radio Telegraphy, organised and supported scientific workers, prosecuting many of the important scientific projects which resulted in Allied supremacy. $\mathrm{He}_{\mathrm{e}}$ was outstanding in the effectiveness of his work for co-operation between British and American scientists, and was responsible for important phases of the early research leading to the development in England and the United States of modern radar.

Prof. P. M. S. Blackett, for exceptionally meritorious conduct in the performance of outstanding services to the United Nations. Prof. Blackett, a British pioneer in the field of operational research, not only played a decisive role in the scientific war activities of his own country, but his inspiring leadership stimulated developments in the United States similar to those initiated by him in Great Britain. His brilliant analysis and interpretation of operation data was a major factor leading to the Allied success in the anti-submarine campaign. The value of his work to the United States was outstanding, and his advice and counsel to us were invaluable contributions to the war effort.

Dr. RoBert CockBurn, for exceptionally meritorious conduct in the performance of outstanding services to the United Nations. Dr. Cockburn, as head of the Counter-measures Group of the Telecommunications Research Establishment in the Ministry of Aircraft Production, was instrumental in devising new electronic techniques to counter the enemy's use of fire control methods, navigation aids and bombing devices. He was one who early appreciated the high importance of electronic intelligence, and devised equipment and analytical methods to seek out this intelligence. He exerted himself to provide for co-operation between British and American scientists. In the field of radio and radar counter-measures, Dr. Cockburn was the British scientist who above all others had the most com. prehensive grasp of the scientific and operational problems involved.

Mr. A. P. Rowe, for exceptionally meritorious conduct in the performance of outstanding services to the United Nations. Mr. Rowe, as head of the great Telecommunications Research Laboratory of the Ministry of Aircraft Production throughout the War, and himself a stimulating and energetic leader of men, exercised a dominant role in the development of radar and counter-measures in the United Kingdom. When American scientists working in these fields proposed to establish advanced laboratories in England, he co-operated enthusiastically, opening his own establishment for their equal use. The inter-Allied discussions at the Telecommunications Research Establishment were famous for their frank- ness and stimulation. Co-operation was strenuously advocated by him; and in the development and employment of electronies in warfare Mr. Rowe made important contribution.

Sir Reginald Stradling, for exceptionally meritorious conduct in the performance of outstanding services to the United Nations. Sir Reginald, as chief adviser on research and experiments to the Ministry of Home Security from 1940 throughout the War, conceived and directed the far-flung British experiments and observations of the effects of bombs. His revolutionary work led to data of vital importance in the air war with Germany. He pioneered in the measurement of blast, which materially affected the entire study of explosive effects culminating with the atomic bomb. He freely made available to the United States the information and resources at his command. He welcomed and trained many young Americans at his Princes Risborough Station in the techniques he had discovered. Sir Reginald's contributions were of invaluable aid to the Allies in time of great peril.

Srr Geoffrey TAYLOR, for exceptionally meritorious conduct in the performance of outstanding services to the United Nations. Sir Geoffrey's researches during the War exercised a notable influence on American investigations. His inquiring intellect penetrated into the depths and brought up certain knowledge. $\mathrm{H}_{\Theta}$ established fundamental truths in fluid dynamics and gas dynamics. He gave inspiration and direction to research in shock-wave propagation, detonation and underwater explosion. His work will continue to influence scientific development, and his contributions were of inestimable value to the war effort.

Sir Henry TIzard, for exceptionally meritorious conduct in the performance of outstanding services to the United Nations. Sir Henry, as leader of the British Technical Mission to the United States in 1940, initiated Anglo-American scientific relations, concluding arrangements for the interchange of information relating to the development of devices for warfare. Later, as scientific advisor to the Air Ministry and member of the Council of the Minister of Aircraft Production, he was a central figure in assuring that research and development as well as operational information of high value in the solution of American problems of aerial warfare, be made available to the United States. Of brilliant mind, gifted with wide imagination, Sir Henry's contribution to the scientific effort of the War was unique.

Sir RoBert WATSON.WATT, for exceptionally meritorious conduct in the performance of outstanding services to the United Nations. An outstanding authority on radar, Sir Robert's years of work, in a field little frequented, largely formed the basis of the extraordinary early success of British radar when the onset of the War engulfed England in a wave of bombing. His keen technical foresight and ability to organise, with his understanding of human nature, were capitalized in the 'Battle for Britain'. The success attained in the military employment of these new scientific devices and methods inspired and stimulated the great radar programme in the United States. He collaborated in every way with American research groups. In the development and effective combat employment of superior types of radar, radar counter-measures and communications equipment, Sir Robert's services were of enormous value. 